\title{
Analisis komparatif self confidence siswa kelas khusus dan kelas reguler
}

\author{
Santoso Santoso ${ }^{1}$, Richma Hidayati $^{\left.1^{*}\right)}$ \\ ${ }^{1}$ Universitas Muria Kudus, Indonesia
}

\begin{tabular}{|c|c|}
\hline Article Info & ABSTRACT \\
\hline $\begin{array}{l}\text { Article history: } \\
\text { Received Jan } 27^{\text {th }}, 2021 \\
\text { Revised Feb } 03^{\text {dd }}, 2021 \\
\text { Accepted Feb } 23^{\text {rd }}, 2021\end{array}$ & $\begin{array}{l}\text { The purpose of this study was to compare the self-confidence of students in } \\
\text { special classes and regular classes and to know class differences. This study } \\
\text { uses a quantitative approach with a comparative design. The research sample } \\
\text { consisted of } 80 \text { students with } 35 \text { regular class students and } 45 \text { special class } \\
\text { students who were determined using the Proportional Random Sampling } \\
\text { Technique. The instrument was adapted from the confidence of the instrument }\end{array}$ \\
\hline $\begin{array}{l}\text { Keyword: } \\
\text { Analisis regresi } \\
\text { Self confidence } \\
\text { Kelas khusus } \\
\text { Kelas reguler }\end{array}$ & $\begin{array}{l}\text { and data analysis used comparational analysis using the Difference Test with } \\
\text { the SPSS program. The conclusion of this study is that there are differences in } \\
\text { the confidence of students in special classes and regular classes. A total of } 30 \\
\text { students in a special class have high self-confidence and } 5 \text { students have a } \\
\text { sufficient level of self-confidence, while students in regular class, as many as } \\
20 \text { students have sufficient self-confidence and } 25 \text { students have less self- } \\
\text { confidence. And shows that the difference between special classes and regular } \\
\text { classes greatly affects the level of student confidence. }\end{array}$ \\
\hline
\end{tabular}

2021 The Authors. Published by Indonesian Institute for Counseling, Education and Therapy (IICET). This is an open access article under the CC Corresponding Author:

Richma Hidayati,

Universitas Muria Kudus

Email: richma.hidayati@umk.ac.id

\section{Pendahuluan}

Kepercayaan diri merupakan salah satu unsur kepribadian yang memegang peranan penting bagi kehidupan manusia. Kepercayaan diri merupakan faktor penting penentu kesuksesan seseorang. Banyak tokoh-tokoh hebat yang mampu menggapai kesuksesan dalam hidup karena mereka memiliki karakter yang disebut kepercayaan diri. Sebagaimana pernyataan yang diungkap oleh Benabou (Benabou, 2014) bahwa self confidence atau kepercayaan diri merupakan model umum yang dimiliki para unggulan (superior performers). Sedangkan spencer (Liu et al., 2019) menyatakan bahwa percaya diri ini menjadi bagian penting dari perkembangan kepribadian seseorang, sebagai penentu atau penggerak bagaimana seseorang bersikap dan bertingkah laku

Kepercayaan diri, sangat berpengaruh terhadap bagaimana orang mengkomparasikan diri dengan orang lain (Kappes et al., 2019). Berdasarkan penelitian (Federič ová et al., 2018) Penurunan kepercayaan diri ini dapat dipicu oleh beberapa mekanisme yang berbeda, seperti peningkatan alami dalam persaingan di kelas, keberangkatan teman sekelas / teman dari kelas, kebijakan guru yang lebih menuntut karena ujian masuk ke sekolah yang lebih tinggi (terutama di ruang kelas di mana lebih banyak siswa sedang mempersiapkan diri untuk ujian tersebut), dan faktor-faktor lainnya. Hasil penelitian Gurler juga menyebutkan bahwa terdapat dua ketegori kepercayaan diri, yang pertama kepercayaan diri ekstrinsik dimana factor dari luar sangat mempengaruhi tinggi rendahnya kepercayaan diri siswa dan yang kedua adalah kepercayaan diri ekstrinsik dimana penilaian diri sangat mempengaruhi tinggi rendahnya kepercayaan diri siswa (Gürler, 2015).

Selama masa ini mereka juga mulai menilai diri mereka sendiri dengan membandingkannya dengan orang lain. Anak anak yang lebih mudah menggunakan perbandingan sosial (social comparison) terutama untuk norma- norma sosial dan kesesuaian jenis- jenis tingkah laku tertentu (Leal et al., 2017). Pada saat anak- anak tumbuh semakin lanjut, mereka cenderung menggunakan perbandingan sosial untuk 
mengevaluasi dan menilai kemampuan kemampuan mereka sendiri. Sebagai akibat dari perubahan struktur fisik dan kognitif mereka, siswa SMA memasuki masa remaja akhir dimana mereka juga mempersiapkan diri untuk memasuki masa Dewasa awal. Mereka ingin diperlakukan sebagai orang dewasa (Jannah, 2017).Terjadi perubahan perubahan yang berarti dalam kehidupan sosial dan emosional mereka. Tidak diterima dalam kelompok dapat membawa pada masalah emosional yang serius Teman- teman mereka menjadi lebih penting daripada sebelumnya. Kebutuhan untuk diterima oleh teman sebaya sangat tinggi. Dan ini membawa pengaruh yang sangat besar terhadap kepercayaan diri mereka ketika di sekolah.

Gurler (Gürler, 2015) menyatakan kepercayaan diri mempunyai kunci karakteristik untuk memulai suatu hal terutama untuk berbicara. Kepercayaan diri menjadi kunci yang sangat penting dalam perkembangan bahasa anak. Dengan kepercayaan diri yang utuh anak tidak akan ragu untuk mengucapkan kata dan berbicara kepada siapa saja dan kecerdasan bahasa anak sangat dipengaruhi oleh kepercayaan dirinya. Percaya diri adalah suatu perasaan dan keyakinan terhadap kemampuan yang dimiliki untuk dapat meraih kesuksesan dengan berpijak pada usahanya sendiri dan mengembangkan penilaian yang positif bagi dirinya sendiri maupun lingkungannya sehingga, seseorang dapat tampil dengan penuh keyakinan dan mampu menghadapi segala sesuatu dengan tenang.

Namun, adakalanya kepercayaan diri yang tinggi menyebabkan meningkatnya kecemasan siswa dalam menghadapi test (Lawal, A. M., Idemudia, E. S., \& Adewale, 2017). Hal ini dikarenakan adanya keinginan siswa untuk memperoleh hasil yang sempurna dalam mengerjakan tes yang dihadapi dan kesempurnaan hasil yang diperoleh akan mempengaruhi kesuksesan dalam akademik, dan pada akhirnya tingginya kepercayaan diri siswa juga berdampak terhadap tingginya kecemasan seseorang. Kepercayaan diri berperan dalam memberikan sumbangan yang bermakna dalam proses kehidupan seseorang. Kepercayaan diri merupakan salah satu modal utama kesuksesan untuk menjalani hidup dengan penuh optimisme dan kunci kehidupan berhasil dan bahagia.

Penjelasan lebih mendalam dikemukakan oleh Lauster (2003) bahwa Kepercayaan diri merupakan sikap dan perasaan yang yakin atas kemampuan pada diri sendiri sehingga individu tidak cemas dalam melakukan suatu tindakan, dapat merasakan kebebasan dalam melakukan hal-hal yang disukai dan mampu untuk bertanggung jawab atas perbuatan yang dilakukan, sopan dan hangat saat berinteraksi dengan orang lain, menghargai serta menerima orang lain, memiliki dorongan untuk menunjukkan keterampilan dan mengetahui kelebihan serta kekurangan pada diri sendiri. Kepercayaan diri tampak pada sikap yang menerima diri sebagaimana adanya (Hariko \& Ifdil, 2017). Penerimaan diri merupakan sikap yang mencerminkan rasa senang sehubungan dengan kenyataan diri sendiri. Sikap tersebut merupakan perwujudan dari kepuasan terhadap kualitas kemampuan diri yang nyata. Reaksi positif seseorang terhadap penampilan dirinya sendiri akan menimbulkan rasa puas yang akan mempengaruhi perkembangan mentalnya (Pettersson, 2018).

Kurangnya kepercayaan diri akan menunjukkan perilaku seperti, tidak bisa berbuat banyak, selalu ragu dalam menjalan tugas, tidak berani berbicara jika tidak mendapatkan dukungan, menutup diri, cenderung sedapat mungkin menghindari situasi komunikasi, menarik diri dari lingkungan, sedikit melibatkan diri dalam kegiatan atau kelompok, menjadi agresif, bersikap bertahan dan membalas dendam perlakuan yang dianggap tidak adil (Schneider et al., 2018). Percaya diri menjadi sikap mental positif seseorang yang memposisikan atau mengkondisikan dirinya sendiri dapat mengevaluasi diri dan lingkungannya sehingga merasa nyaman untuk melakukan kegiatan dalam upaya mencapai tujuan yang direncanakan. Kepercayaan diri merupakan sikap yang memungkinkan individu memiliki pandangan positif dan realistis tentang diri mereka sendiri dan situasi mereka.

Kepercayaan diri yang dimiliki siswa menjadikan siswa mampu memahami kemampuan yang dimiliki sehingga memiliki dorongan untuk mencapai tujuan. Dengan kepercayaan diri yang bagus, mereka pun mampu untuk menyelesaikan permasalahan dan pekerjaan yang menjadi tanggung jawab mereka sendiri sehingga, semakin individu kehilangan suatu kepercayaan diri, maka akan semakin sulit untuk memutuskan yang terbaik apa yang harus dilakukan kepada dirinya, dan cenderung akan kehilangan motivasi (Fitri et al., 2018) dalam melakukan banyak hal terutama belajar.

Kepercayaan diri sangat penting bagi siswa. Potensi siswa dapat berkembang dan meningkat Ketika siswa memiliki kepercayaan diri yang utuh sehingga dapat meningkatkan perkembangannya baik oleh dirinya sendiri maupun lingkungan yang akan membantu pencapaian tujuan. Siswa yang percaya diri memiliki keoptimisan akan kemampuan yang dimiliki dalam pencapaian tujuan yang telah ditetapkan (Aristiani, 2016). 
Kepercayaan diri menjadi penting untuk dimiliki siswa karena kepercayaan diri merupakan salah satu karakter yang harus dimiliki siswa yang sesuai dengan Penguatan Pendidikan Karakter (PPK) sebagai implementsi dari amanat Nawacita. Penguatan pendidikan karakter di sekolah harus dapat menumbuhkan karakter siswa untuk dapat Critical Thinking (Herawati et al., 2019) and Problem Solving (berpikir kritis dan menyelesaikan masalah), Creativity (kreativitas), Communication Skills (kemampuan berkomunikasi) (Nadiah \& Arina, 2019), dan Ability to Work Collaboratively (kemampuan untuk bekerja sama) (Gulam Abbas and Allah Nawaz, 2020), yang mampu bersaing di abad 21. Dan kepercayaan diri sangat mempengaruhi terbentuknya keempat komptensi tersebut.

Kepercayaan diri tumbuh dan berkembang melalui proses belajar dan pembelajaran baik di sekolah maupun di luar sekolah, oleh karena itulah kepercayaan diri merupakan sikap yang harus ada pada siswa. Kurangnya kepercayaan diri muncul karena adanya ketakutan, keresahan, khawatir, rasa tak yakin yang diiringi dengan dada berdebar- debar kencang dan tubuh gemetar yang bersifat kejiwaan atau masalah kejiwaan anak yang disebabkan rangsangan dari luar (Zufriadi Tanjung, 2018) Selain itu rasa kurang percaya diri bisa juga disebabkan oleh perasaan cemas dan tidak tenang serta perasaan-perasaan lain yang mengikutinya seperti malas, kurang sabar, sulit, susah atau rendah diri (Deni, 2016). Siswa yang mempunyai rasa percaya diri tinggi dapat memahami kelebihan dan kelemahan yang dimiliki. Percaya diri merupakan aspek yang sangat penting bagi siswa untuk dapat mengembangkan potensinya. Jika seseorang memiliki bekal percaya diri yang baik, maka individu tersabut akan dapat mengembangkan potensinya dengan mantap. Namun jika siswa memiliki percaya diri rendah, maka individu tersebut cenderung menutup diri, mudah frustasi ketika menghadapi kesulitan, canggung dalam menghadapi orang, dan sulit menerima realita dirinya. Dengan percaya diri saat maju didepan kelas, dapat meningkatkan keberanian siswa dalam menjawab pertanyaan. Selain itu dapat meningkatkan komunikasi dengan baik, memiliki ketegasan, mempunyai penampilan diri yang baik, dan mampu mengendalikan perasaan. Memiliki percaya diri yang tinggi dalam diri siswa dapat membantu mencapai prestasi dan hasil belajar yang lebih baik lagi. Dengan begitu akan terjadi proses perubahan dalam diri siswa bukan hanya pada hasil belajar tetapi juga pada perilaku dan sikap siswa, yaitu keberanian, keaktifan, dan aktualisasi diri siswa saat proses belajar mengajar.

Berdasarkan hasil penelitian mengungkapkan bahwa siswa di SMA memiliki kepercayaan diri yang rendah (Dyesi Kumalasari, 2017; Marjanti, 2015; Pranoto, 2016; Wahyu Nanda Eka Saputra, 2018; Walid et al., 2015) dan sebagian kecil siswa yang memiliki kepercayaan diri yang tinggi. Berdasarkan Fenomena yang terjadi di MA NU Banat Kudus, dimana siswa dikelas reguler memiliki kepercayaan diri yang rendah, hal ini terlihat dari Siswa (a) mengalami kesulitan mengutarakan pendapat di dalam kelas, (b) ragu-ragu bertanya kepada guru, (c) mengalami kesulitan berbicara dalam melakukan presentasi di depan kelas, (d) ragu-ragu jika ingin menjawab pertanyaan guru (e) motivasi berpretasi di tingkat nasional dan internasional yang rendah, (f) merasa tidak sebaik siswa di kelas khusus (g) merasa malu jika berhadapan dengan orang banyak (h) takut berbicara di depan umum. Fenomena ini berbading terbalik dengan siswa di kelas yang sama namun berada di dalam kelas khusus, dimana siswa di kelas khusus selalu bertanya disetiap kesempatan, tidak ada keraguan dalam menjawab pertanyaan yang diajukan oleh guru dan mengajukan diri Ketika ada kesempatan untuk mengikuti event-event internasional.

Oleh karena itu, berdasarkan fenomena yang terjadi, Penelitian ini focus pada menganalisisis perbedaan kepercayaan diri di kelas reguler dan kelas khusus di Madarasah Aliyah Nahdlotul Ulama Banat (MA NU Banat) di Kabupaten Kudus, dikerenakan tren pembagian kelas reguler dan kelas khusus sangat populer di Jawa Tengah. Sehingga dalam penelitian ini mampu mengungkapkan komparasi kepercayaan diri di kelas reguler dan kelas khusus dan mengungkapkan bahwa perbedaan kelas khusus dan kelas reguler akan mempengaruhi kepercayaan diri siswa

\section{Metode}

Penelitian ini menggunakan pendekatan kuantitatif dengan desain komparatif. Subjek pnelitian adalah siswa Kelas XI kelas reguler dan kelas khusus. Sampel penelitian berjumlah 80 siswa Madarasah Aliyah Nahdlotul Ulama Banat (MA NU Banat), dimana 35 siswa merupakan siswa dari kelas khusus dan 45 siswa dari kelas reguler dengan Teknik proporsional Random sampling. Intrumen penelitian menggunakan observasi kepada siswa, wawancara kepada guru BK dan Skala kepercayaan diri yang diadaptasi dari Skala Kepercayaan diri Lauster (2013). Analisis data menggunakan analisis komparasional dengan Uji Beda menggunakan Uji T test (independent sample t test) melalui program SPSS versi 25. 


\section{Hasil dan Pembahasan}

Hasil analisis deskriptif komparatif tentang kepercayaan diri siswa Kelas Khusus dan Kelas Reguler dapat dijelaskan pada tabel berikut ini.

Tabel 1. Kepercayaan Diri

\begin{tabular}{clcccc}
\hline No & \multicolumn{1}{c}{ Kategori } & Kelas Khusus & Kelas Regular & Interval \\
\hline & $\mathbf{1}$ & Tinggi & 30 & 0 & $31-45$ \\
& $\mathbf{2}$ & Cukup & 5 & 20 & $16-30$ \\
& $\mathbf{3}$ & Kurang & 0 & 25 & $0-15$ \\
& TOTAL & 35 & 45 & \\
\hline
\end{tabular}

Berdasarkan tabel di atas dapat diketahui bahwa siswa di kelas khusus masuk dalam kategori kepercayaan diri yang tinggi sedangkan siswa di kelas regular masuk dalam kategori kepercayaan diri yang cukup dan rendah. Hasil Uji beda, menunjukkan adanya perbedaan kepercayaan diri siswa di kelas khusus dan di kelas regular. Sejumlah 30 siswa di kelas khusus masuk dalam kategori kepercayaan diri yang tinggi dan 5 siswa masuk dalah kategori kepercayaan diri yang cukup. Sedangkan siswa di kelas reguler, sejumlah 20 siswa masuk dalam kategori kepercayaan diri yang cukup dan 25 siswa dalam kategori rendah. Hasil penelitian ini telah memberikan gambaran akan perbedaan kelas khusus dan kelas regular mempengaruhi tingkat kepercayaan diri siswa.

Hasil pengujian hipotesis dengan menggunakan uji menggunakan uji beda) yakni terdapat $p>0,05$, yakni sebesar $\mathrm{p}=0,027$ dengan nilai t sebesar 2,226 yang artinya, ada perbedaan kepercayaan diri siswa di kelas khusus dan kelas reguler. Kesimpulan ini diperoleh dari hasil uji-t penelitian ini menunjukkan adanya perbedaan nilai rata-rata (mean) pada variabel kepercayaan diri siswa khusus sebesar 115,86 dan pada siswa reguler sebesar 112,32. Berdasarkan hasil tersebut menunjukkan bahwa kepercayaan diri pada siswa kelas Khusus lebih tinggi dari pada siswa reguler. Karakteristik siswa kelas khusus lebih percaya diri dan aktif untuk berhubungan dengan siswa baik dalam kelas sendiri maupun dengan kelas reguler lainnya. Jika dibandingkan dengan siswa kelas reguler memiliki karakteristi tidak aktif dalam bersosialisasi dengan siswa lainnya.

Siswa kelas khusus mendapatkan beberapa perlakuan khusus. Sejak awal siswa diseleksi secara baik dengan menggunakan kriteria dan prosedur tertentu, jumlah jam waktu belajar di sekolah yang lebih lama dibandingkan dengan kelas pada umumnya, sarana dan prasarana yang lebih menunjang untuk memenuhi belajar peserta didik baik dalam kegiatan intra maupun eksra kurikuler, guru dan tenaga pengajar yang unggul dan profesional, buku belajar dan soal latihan yang lebih menunjang dan jumlah siswa dikelas maksimal sampai 35 siswa sehingga dapat lebih efektif. Berdasarka dari berbagai ciri diatas dapat dilihat beberapa perbedaan perlakuan dari sistem pengajaran hingga fasilitas yang diberikan pada kelas khusus berdampak pada kepercayaan diri siswanya.

Kepercayaan diri dipengaruhi oleh beberapa faktor yaitu konsep diri, harga diri, pengalaman dan pendidikan. Pengembangan percaya diri dapat dipelajari dengan melihat berbagai faktor penting dalam mempercepat tumbuh dan berkembangnya percaya diri. Beberapa faktor tersebut adalah: Penampilan/Style, Gaya bertutur kata/ Speaking (Cimermanová, 2018), Gaya bertingkah laku/Bodylanguage, right man in the right place (Vanaja \& Geetha, 2017). Proses meraih prestasi dipengaruhi oleh faktor aktivitas, organisme dan faktor lingkungan(Kastrup et al., 2018). Faktor aktivitas, yaitu faktor yang memberikan dorongan kepada individu untuk belajar, faktor ini merupakan faktor psikologi. Kepercayaan diri merupakan faktor aktivitas. Faktor organisme, yaitu faktor yang berhubungan dengan fungsi alat-alat indra individu yang kepekaannya ikut menentukan respon individu dalam belajar. Faktor lingkungan, yaitu faktor yang secara psikologis mempengaruhi proses secara keseluruhan.

Berdasarkan hasil studi lapangan yang dilakukan peneliti sebelumnya juga menguatkan hasil penelitian. Menurut hasil pengamatan di kelas-kelas reguler saat jam pelajaran berlangsung, siswa memiliki kepercayaan diri yang rendah yang ditunjukkan dengan siswa mengalami kesulitan mengutarakan pendapat di dalam kelas, Ketika belum memahami materi pelajaran para siswa ragu-ragu bertanya kepada guru, Ketika diminta melakukan presentasi didepan kelas sebagain besar siswa memiliki kesulitan berbicara, raguragu jika ingin menjawab pertanyaan, ketika ditunjuk oleh guru untuk mengikuti lomba baik ditingkat nasional maupun internasional sebagain besar menolak dan mundur. Hal ini didukung dengan hasil 
wawancara terhadap beberapa siswa di kelas reguler bahwa siswa di kelas reguler merasa tidak sebaik siswa di kelas khusus, merasa malu jika berhadapan dengan orang banyak dan takut berbicara di depan umum.

Lingkungan sekolah menjadi factor utama dalam kepercayaan diri siswa. Kelas khusus dan kelas regular di MA NU banat memberikan suasana dan lingkungan yang berbeda kepada siswa yang akhirnya memunculkan Perbedaan Kepercayaan diri siswa di tiap kelas. Kelas khusus, dengan siswa yang keseluruhannya memiliki kepercayaan diri yang tinggi, ditandai dengan: ketika di dalam kelas lebih aktif, tidak malu untuk bertanya ketika diberikan kesempatan untuk bertanya, Ketika di minta untuk maju ke depan dan menyelesaikan soal-soal, mereka berebut untuk menjawab pertanyaan, ketika tematik yang membahas matematika ada dua anak yang mengacungkan jari dan meminta dijelaskan kembali karena belum faham dan itu artinya mereka memahami kelemahan yang dimiliki, mereka juga mampu mengutarakan apa yang ada dalam dirinya hal ini terbukti dengan mereka bisa mengungkapkan pendapat masing-masing ketika ditanya oleh guru yang sedang mengajar.

Kondisi ini berbeda dengan kelas regular, dan semakin terlihat sangat mencolok ketika di kelas regular tersebut terdapat anak dengan kecerdasan yang menonjol, siswa yang tidak bisa cenderung langsung diam, di dalam kelas tidak banyak bicara, bahkan dengan teman sekelasnya tidak banyak berbincang satu sama lain, Ketika di minta guru yang mengajar untuk maju mengerjakan soal mereka enggan maju ke depan, Siswa juga menunjukkan kepercayaan diri yang rendah ketika dihadapkan dalam kelompok, khusunya jika di dalam kelompok tersebut terdapat anak yang yang pintar, mereka lebih memilih diam dan tidak bisa mengutarakan pendapat atau apa yang dipikirkan dan ini muncul ketika tematik penjarorkes dengan kegiatan kelompok diluar ruangan.

Hasil pengujian hipotesis pada penelitian ini menunjukkan adanya perbedaan yang signifikan antara kepercayaan diri siswa di kelas khusus dan di kelas regular. Hal ini berarti bahwa banyak factor yang mempengaruhi kepercayaan diri siswa khususnya siswa sekolah dasar. Sejalan dengan penelitian (Flowers \& Marston, 2017), menjelaskan perbedaan gender menjadi salah satu fakor yang menyebabkan perbedaan kepercayaan diri siswa. Gender (perbedaan antara laki-laki dan perempuan) memang bisa menjadi salah satu factor yang menjadikan tinggi rendahnya kepercayaan diri siswa, namun dalam penelitian ini yang menjadi subjek penelitian adalah semua siswa adalah perempuan karena memang sekolah khusus perempuan dan yang membedakan adalah perbedaan kelas khusus dan kelas regular di setiap tingkat kelas, sehingga perbedaan kelas khusus dan kelas regular ini juga menjadi salah satu factor yang menyebabkan perbedaan kepercayaan diri siswa.

Kepercayaan diri merupakan suatu keyakinan yang dimiliki seseorang bahwa dirinya mampu berperilaku seperti yang dibutuhkan untuk memperoleh hasil seperti yang diharapkan (Lestari et al., 2019). Sejalan dengan hasil penelitian Aldert Vrij \& Nicola Bush Tingkat kepercayaan diri anak-anak diukur dengan enam item dari Behavioral Academic Self Esteem Scale (BASE), yang mencerminkan kepercayaan diri dan diperoleh hasil Anak-anak yang lebih muda lebih mudah dibujuk daripada anak-anak yang lebih tua dan perbedaan ini menghilang ketika dikendalikan untuk kepercayaan diri. Selain usia, terdapat banyak factor yang mempengaruhi kepercayaan diri siswa (Vrij \& Bush, 2000).

Kesenjangan gender dapat mempengaruhi kepercayaan diri siswa yang dihasilkan dari faktor lingkungan sekolah yang kompetitif (Federič ová et al., 2018). Dalam penelitian ini sejalan dengan dengan hasil penelitian (Federič ová et al., 2018), melihat perbedaan yang muncul di kelas khusus dan kelas regular yang menjadi lingkungan belajar para siswa, ketika siswa di kelas regular di gabungkan dalam kelompok dengan kelas khusus (full day class), kepercayaan diri mereka semakin menurun dan mereka akan lebih banyak diam.

Lingkungan dan suasana akademik membawa pengaruh yang sangat besar dalam kepercayaan diri siswa. Perbedaan perlakukan di dalam kelas khusus dan kelas regular dalam penciptaan suasana akademik dalam proses pembelajaran menjadi penyebab perbedaan tingkat kepercaaayn diri siswa. Sejalan dengan penelitian Bolivar dkk (Bolívar-Cruz et al., 2018) yang menjelaskan bahwa kepercayaan diri siswa, self efficacy dan insentive penilaian dalam diri siswa membawa dampak dalam kompetensi presentasi lisan dalam suasana akademik. Karena itu, dalam melihat perbedaan gender, perlakuan yang diberikan dalam suasana akademik akan berbeda. Hasil penelitian Bolivar dkk mendukung penelitian ini, karena perbedaan kelas regular dan kelas khusus yang paling mencolok adalah perbedaan fasilitas kelas sehingga mempengaruhi suasana akademik di dalam kelas yang pada akhirnya memunculkan perbedaan tingkat kepercayaan diri siswa.

Berdasarkan hasil pengujian hipotesis diketahui, bahwa siswa di kelas khusus memiliki tingkat kepercayaan diri yang tinggi sedangkan siswa di kelas regular cenderung memiliki kepercayaan diri yang rendah. Hal tersebut sesuai dengan pendapat Kepercayaan diri merupakan suatu sikap atau keyakinan atas 
kemampuan diri sendiri, sehingga dalam tindakan-tindakannya tidak terlalu cemas (Passiatore et al., 2019), merasa bebas untuk melakukan hal-hal yang sesuai dengan keinginan (Komara, 2016) dan tanggung jawab atas perbuatannya (Ramadhani et al., 2014), sopan dalam berinteraksi dengan orang lain (Wahyu Nanda Eka Saputra, 2018), memiliki dorongan prestasi (Komara, 2016; Walid et al., 2015) serta dapat mengenal kelebihan dan kekurangan diri sendiri (Hooper, 2018). Terbentuknya kemampuan percaya diri adalah suatu proses belajar bagaimana merespon berbagai rangsangan dari luar dirinya melalui interaksi dengan lingkungannya. Perbedaan interaksi di kelas khusus dan kelas reguler juga sangat besar pengaruhnya terhadap kepercayaan diri siswa.

Rasa percaya diri bukan merupakan sifat yang diturunkan (bawaan) melainkan diperoleh dari pengalaman hidup, serta dapat diajarkan dan ditanamkan melalui pendidikan, sehingga upaya-upaya tertentu dapat dilakukan guna membentuk dan meningkatkan rasa percaya diri. Dengan demikian kepercayaaan diri terbentuk dan berkembang melalui proses belajar di dalam interaksi seseorang dengan lingkungannya. Pembedaan siswa ke dalam kelas khusus dan kelsa reguler memunculkan permasalahan yang sangat krusial khususnya dalam kepercayaan diri siswa. Sehingga terjadi perbedaan tingkat kepercayaan diri siswa di kelas khusus dan kelas reguler.

\section{Simpulan}

Adapun kesimpulan dari penelitian ini adalah terdapat perbedaan kepercayaan diri siswa MA NU Banat Kudus di kelas khusus dan kelas reguler. Sebanyak Siswa 30 siswa di kelas khusus memiliki kepercayaan diri yang tinggi dan 5 siswa memiliki tingkat kepercayaan diri yang cukup sedangkan siswa di kelas reguler, sebanyak 20 siswa memiliki kepercayaan diri yang cukup dan 25 siswa memiliki kepercayaan diri yang kurang. Berdasarkan hasil penelitian ini, mampu menambah wawasan dan pengetahuan mengenai faktorfaktor yang mempengaruhi kepercayaan diri, salah satunya adalah perbedaan kelas khusus dan kelas reguler sangat mempengaruhi tingkat kepercayaan diri siswa. Selain itu, penelitian ini juga memberikan landasan bagi para peneliti lain dalam melakukan penelitian lain yang sejenis dalam rangka meningkatkan kepercayaan diri siswa.

\section{Referensi}

Aristiani, R. (2016). Meningkatkan Percaya Diri Siswa Melalui Layanan Informasi BErbantuan Audiovisual. Konseling Gusjigang, 2(2), 182-189. jurnal.umk.ac.id

Benabou, R. (2014). Self-Confidence And Personal Motivation. Quarterly Journal of Economics, June. https://doi.org/10.1162/003355302760193913

Bolívar-Cruz, A., Verano-Tacoronte, D., \& Galván-Sánchez, I. (2018). Do self-efficacy, incentives and confidence in public speaking influence how students self-assess? Cultura y Educacion, 30(3), 528-555. https://doi.org/10.1080/11356405.2018.1488420

Cimermanová, I. (2018). The effect of learning styles on academic achievement in different forms of teaching. International Journal of Instruction, 11(3), 219-232. https://doi.org/10.12973/iji.2018.11316a

Deni, A. U. (2016). KONSEP KEPERCAYAAN DIRI REMAJA PUTRI. Educatio, Jurnal Pendidikan Indonesia, 2(2), 43-52. http://jurnal.iicet.org

Dyesi Kumalasari. (2017). Konsep Behavioral Therapy dalam Meingkatkan Rasa Percaya Diri Pada Siswa Terisolir. Hisbah: Jurnal Bimbingan Konseling Dan Dakwah Islam, 14(1), 15-24. ejournal.uin-suka.ac.id

Federičová, M., Pertold, F., \& Smith, M. L. (2018). Children left behind: self-confidence of pupils in $\begin{array}{llll}\text { competitive environments. Education } & \text { Economics, }\end{array}$ https://doi.org/10.1080/09645292.2017.1395811

Fitri, E., Zola, N., \& Ifdil, I. (2018). Profil Kepercayaan Diri Remaja serta Faktor-Faktor yang Mempengaruhi. JPPI (Jurnal Penelitian Pendidikan Indonesia), $4(1), \quad 1$. https://doi.org/10.29210/02017182

Flowers, J., \& Marston, A. (1972). Modification of low self-confidence in elementary school children. Journal of Educational Research, 66(1), 30-34. https://doi.org/10.1080/00220671.1972.10884394

Gulam Abbas and Allah Nawaz. (2020). LINKING EMPLOYEE MOTIVATION WITH TEAMWORKSPIRIT: THE INFLUENCE OF SOCIAL SKILLS AND SELF-CONFIDENCE. Gomal University Journal of Research, 36(1), 52-62.

Gürler, I. (2015). Correlation between Self Confidence and Speaking Skill. Curr Res Soc Sci, 1(2), 14-19.

Hariko, R., \& Ifdil, I. (2017). Analisis Kritik Terhadap Model Kipas; Konseling Intensif Progresif Adaptif Struktur. Jurnal Konseling Dan Pendidikan, 5(2), 109. https://doi.org/10.29210/120500 
Herawati, E., Somatanaya, A. A. G., \& Hermanto, R. (2019). Hubungan Self-Confindence dan Kemampuan Berpikir Kreatif Matematik Peserta Didik yang diajar Menggunakan Model Elicting Activities (MEAs). Journal of Authentic Research on Mathematics Education (JARME), 1(1), 1-9. http://jurnal.unsil.ac.id/index.php/jarme/article/view/621

Hooper, C. (2018). The Mahabharata. Psychological Perspectives, 61(1), 76-91. https://doi.org/10.1080/00332925.2018.1422931

Jannah, M. (2017). Remaja Dan Tugas-Tugas Perkembangannya Dalam Islam. Psikoislamedia: Jurnal Psikologi, 1(1), 243-256. https://doi.org/10.22373/psikoislamedia.vli1.1493

Kappes, H. B., Fasolo, B., Han, W., Barnes, J., \& Ter Meer, J. (2019). Poor peer work does not boost student confidence. Journal of Behavioral Decision Making, January, 1-12. https://doi.org/10.1002/bdm.2148

Kastrup, H., Mallow, J. V, Lestari, H. P., Hartoto, S., Khory, F. D., \& Prakoso, B. B. (2018). The effectiveness of collaborative problem based physics learning ( CPBPL ) model to improve student 's self-confidence on physics learning The effectiveness of collaborative problem based physics learning ( CPBPL ) model to improve s tudent' s self-con. IOP Conf. Series: Journal of Physics: Conf. Series 997 (2018) 012008. https://doi.org/doi :10.1088/1742-6596/997/1/012008

Komara, I. B. (2016). Hubungan antara Kepercayaan Diri dengan Prestasi Belajar dan Perencanaan Karir Siswa. Jurnal Psikopedagogia, 5(1), 33-42. journal.uad.ac.id

Lawal, A. M., Idemudia, E. S., \& Adewale, O. P. (2017). Academic self-confidence effects on test anxiety among nigerian university students. Journal of Psychology in Africa, 27(6), 507-510. https://doi.org/10.1080/14330237.2017.1375203

Leal, P. C., Goes, T. C., da Silva, L. C. F., \& Teixeira-Silva, F. (2017). Trait vs. state anxiety in different threatening situations. Trends in Psychiatry and Psychotherapy, 39(3), 147-157. https://doi.org/10.1590/2237-6089-2016-0044

Lestari, T., Mulyana, E. H., Nurzaman, I., Gandana, G., \& Apriyaningsih, E. (2019). Exploring the integrating potentials of role playing with YouTube in building student's self confidence. Journal of Physics: Conference Series, 1318(1). https://doi.org/10.1088/1742-6596/1318/1/012014

Liu, X., Xu, Y., Montes, R., \& Herrera, F. (2019). Social network group decision making: Managing selfconfidence-based consensus model with the dynamic importance degree of experts and trust-based feedback mechanism. Information Sciences, $215-232$. https://doi.org/https://doi.org/10.1016/j.ins.2019.07.050

Marjanti, S. (2015). Upaya Meningkatkan Rasa Percaya Diri Melalui Konseling Kelompok Bagi Siswa X IPS 6 SMA 2 BAE Kudus. Konseling Gusjigang, 1(2). jurnal.umk.ac.id

Nadiah, \& Arina, I. (2019). The Students' Self-Confidence in Public Speaking. ELITE Journal, 1(1), 1-11. https://www.elitejournal.org/index.php/ELITE

Passiatore, Y., Pirchio, S., Oliva, C., Panno, A., \& Carrus, G. (2019). Self-efficacy and anxiety in learning English as a Foreign language: Singing in class helps speaking performance. Journal of Educational, Cultural and Psychological Studies, 2019(20), 121-138. https://doi.org/10.7358/ecps-2019-020-passi

Pettersson, C. (2018). Psychological well-being, improved self-confidence, and social capacity: bibliotherapy from a user perspective. Journal of Poetry Therapy, 31(2), 124-134. https://doi.org/10.1080/08893675.2018.1448955

Pranoto, H. (2016). Upaya Meningkatkan Percaya diri Siswa Melalui Layanan Bimbingan Kelompok di SMA Negeri 1 Sungkai Utara Lampung Utara. Lentera Jurnal Pendidikan Pusat Penelitian LPPM UM Metro, 1(1), 100-111. https://doi.org/http://dx.doi.org/10.24127/jlplppm.v1i1.108

Ramadhani, T. N., Putrianti, F. G., Psikologi, F., \& Tamansiswa, U. S. (2014). Hubungan antara kepercayaan diri dengan citra diri pada remaja akhir. Jurnal UST Jogja, 4(2), 22-32.

Schneider, R., Lotz, C., \& Sparfeldt, J. R. (2018). Smart, confident, interested: Contributions of intelligence, self-concept, and interest to elementary school achievement. Learning and Individual Differences, 62, 2335. https://doi.org/https://doi.org/10.1016/j.lindif.2018.01.003

Vanaja, Y., \& Geetha, D. (2017). A Study on Locus of Control and Self Confidence of High School Students. International Journal of Research Granthaalayah, 5, 598-602. https://doi.org/10.5281/zenodo.841186

Vrij, A., \& Bush, N. (2000). Differences in suggestibility between 5-6 and 10-11 year olds: The relationship with self confidence. Psychology, Crime and Law, 6(2), 127-138. https://doi.org/10.1080/10683160008410837

Wahyu Nanda Eka Saputra, H. P. (2018). Meningkatkan Percaya Diri Siswa melalui Teknik Cognitive Defusion. Jurnal Kajian Bimbingan Dan Konseling, 3(1), 14-21. http://journal2.um.ac.id/index.php/jkbk

Walid, A., Gamal, R., Kusumah, T., Doktoral, P., \& Doktoral, P. (2015). Pengaruh Rasa Percaya Diri 
Terhadap Motivasi Berprestasi Siswa pada Mata Pelajaran IPA. Repository Iain Bengkulu, 217-226.

Zufriadi Tanjung, dkk. (2018). Menumbuhkan Kepercayan Diri Siswa. Jurnal Riset Tindakan Indonesia, 2(2),

2-6. Riset, J., Indonesia, T., \& Artikel, I. (2018). Menumbuhkan Kepercayan Diri Siswa. Jurnal Riset Tindakan Indonesia, 2(2), 2-6. 